\title{
Silencing of mutant p53 by siRNA induces cell cycle arrest and apoptosis in human bladder cancer cells
}

\author{
Hai-Bin Zhu ${ }^{2 \dagger}$, Kai Yang ${ }^{1 \dagger}$, Yan-Qi Xie', Yi-Wei Lin', Qi-Qi Mao ${ }^{1}$ and Li-Ping Xie ${ }^{1 *}$
}

\begin{abstract}
Background: p53 is the most frequently mutated tumor-suppressor gene in human cancers. It has been reported that mutations in p53 result not only in the loss of its ability as a tumor suppressor, but also in the gain of novel cancer-related functions that contribute to oncogenesis. The present study evaluated the potential of silencing of mutant p53 by small interfering RNA in the treatment of bladder cancer cells in vitro.

Methods: We used the 3-(4,5-dimethylthiazol-2-yl)-2,5-diphenyltetrazolium bromide (MTT) assay to assess cell viability and flow cytometry to detect cell cycle alterations and apoptosis. The related molecular mechanisms were assessed by western blotting. We also used the MTT assay and flow cytometry to investigate if silencing of mutant p53 by knockdown with small interfering (si)RNA would change the sensitivity to cisplatin treatment.

Results: Using 5637 and T24 human bladder cancer cell lines characterized by mutations in p53, we found that silencing of the mutant p53 by RNA interference induced evident inhibition of cell proliferation and viability, which was related to the induction of G2 phase cell cycle arrest and apoptosis. Moreover, our study also showed that the p53-targeting siRNA cooperated with cisplatin in the inhibition of bladder cancer cells.
\end{abstract}

Conclusions: These findings suggest that RNA interference targeting mutant p53 may be a promising therapeutic strategy for the treatment of bladder cancer.

Keywords: Mutant p53, RNA interference, Bladder cancer, Cisplatin, Apoptosis

\section{Background}

Bladder cancer is the fourth most common cancer in men, with an estimated 73,510 new cases of and 14,880 deaths from bladder cancer in the USA In 2012 [1]. Although chemotherapy has revolutionized the treatment of advanced tumors [2,3], cisplatin-containing combination chemotherapy for metastatic disease achieves only a median survival of up to 14 months [4], and the associated side-effects induced by its lack of specificity for tumor cells remain a challenging problem. Therefore, novel therapeutic strategies for the treatment of advanced bladder cancer are urgently required.

\footnotetext{
* Correspondence: Ipxie@yahoo.cn

${ }^{\dagger}$ Equal contributors

'Department of Urology, The First Affiliated Hospital, School of Medicine, Zhejiang University, Qingchun Road 79, Hangzhou, Zhejiang Province 310003, China

Full list of author information is available at the end of the article
}

The well-known tumor suppressor p53 (encoded by the human gene TP53), which functions primarily as a transcription factor, plays a vital role in protecting cells from a variety of cellular stresses, including DNA damage and oncogene activation. These stresses trigger the accumulation of p53 protein and activate its transcriptional activity, which prevents cell transformation by inducing cell cycle arrest, senescence, apoptosis, DNA repair, or autophagy $[5,6]$. TP53 mutations occur in approximately half of all human cancers, and the majority abrogates the sequencespecific DNA-binding activity of the p53 protein, which constitutes a corner-stone in tumorigenesis [7-9]. Moreover, these mutations usually exert cancer-promoting effects, not only by dominant-negative inactivation of the remaining wild-type allele $[10,11]$, but also through authentic oncogenic gain-of-function activities, which include a wide range of newly acquired oncogenic properties that are not found in the wild-type p53, such as increased

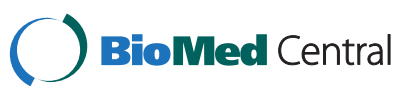

(c) 2013 Zhu et al.; licensee BioMed Central Ltd. This is an Open Access article distributed under the terms of the Creative Commons Attribution License (http://creativecommons.org/licenses/by/2.0), which permits unrestricted use, distribution, and reproduction in any medium, provided the original work is properly cited. 
genomic instability and cell proliferation, augmented invasion and metastasis, and drug resistance and inhibition of apoptosis [12], underlying the evidence for the association of TP53 mutations with poor clinical outcome in a variety of cancer types. In support of the gain-of-function hypothesis, stable or conditional knockdown of endogenous p53 mutants in various human cancer cell lines were shown to reduce their proliferation rate and chemoresistance in vitro, and their ability to form tumors in nude mice $[13,14]$.

Alterations in the p53 gene and its pathways are usually implicated in muscle-invasive bladder cancer (T2-T4) and advanced stages, and are associated with augmented angiogenesis, invasiveness, metastasis, recurrence, and consequent poor prognosis $[15,16]$. However, there have been conflicting findings on whether p53 mutations confer increased responsiveness or resistance to cisplatin-based systemic chemotherapy in bladder cancer [17]. In this study, we chose as models two bladder cancer cell lines, T24 and 5637, which both have p53 mutations. The T24 cell line was found to contain a p53 mutation with an inframe deletion of tyrosine 126 [18], while the 5637 cells carried the p53R280T mutant [19]. Our study showed that knockdown of these p53 mutants by small interfering (si) RNA not only induced cell cycle arrest and cell apoptosis in T24 and 5637 bladder cancer cell lines, but also cooperated with cisplatin in the inhibition of these cancer cells, suggesting that siRNAs may serve as alternative agents for the treatment of bladder cancer by targeting mutant $\mathrm{p} 53$.

\section{Methods}

\section{Reagents}

The p53-targeting siRNA used was siP53 (Santa Cruz Biotechnology Inc., Santa Cruz, CA, USA). The control double-stranded small RNA siCon (Table 1) was designed to lack significant homology to all known human sequences and chemically synthesized (GeneChem; Shanghai, China). We used primary immunoblotting antibodies against $\beta$ actin, phospho-cyclin-dependent kinase (CDK)1, phosphoCDK2, cyclin A, cyclin B1, cyclin D1, and cyclin E (Cell Signaling Technologies, Beverly, MA, USA), and antibodies against poly(ADP-ribose) polymerase (PARP), CDK1, CDK2, CDK4, caspase-3, caspase-9, and p53 (Santa Cruz Biotechnology Inc., Santa Cruz, CA, USA). This study has been approved by the ethics committee of Zhejiang

Table 1 Sequences of RNA and primers used in this study

\begin{tabular}{lll}
\hline Name & Direction & Sequence $\mathbf{5}^{\prime} \rightarrow \mathbf{3}^{\prime}$ \\
\hline siCon & Sense & ACUACUGAGUGACAGUAGA[dT][dT] \\
& Anti-sense & UCUACUGUCACUCAGUAGU[dT][d]] \\
P53 & Forward & TGCGTGTGGAGTATTTGGATG \\
& Reverse & TGGTACAGTCAGAGCCAACCTC \\
GAPDH & Forward & AAGGTGAAGGTCGGAGTCA \\
& Reverse & GGAAGATGGTGATGGGATT \\
\hline
\end{tabular}

University and performed according to our institutional guidelines.

\section{Cell culture and transfection}

The human bladder cancer cell lines 5637 and T24 (Shanghai Institute of Cell Biology, Chinese Academy of Science, Shanghai, China) were cultured in RPMI 1640 medium supplemented with $10 \%$ heat-inactivated fetal bovine serum, $100 \mathrm{U} / \mathrm{ml}$ penicillin, and $100 \mathrm{mg} / \mathrm{l}$ streptomycin in a humidified atmosphere containing $5 \% \mathrm{CO}_{2}$ maintained at $37^{\circ} \mathrm{C}$. The day before transfection, cells were plated in growth medium without antibiotics at a density of $30-40 \%$. Transfections of double-stranded (ds)RNA were carried out using transfection reagent (Lipofectamine 2000; Invitrogen, Carlsbad, CA, USA), in accordance with the manufacturer's protocol. Mock groups were treated with the transfection reagent only. All cell groups were incubated for 24 or 48 hours. Cell images were taken using a phase-contrast microscope at $\times 100$ magnification (Olympus, Japan).

\section{Real-time quantitative PCR}

Total RNA was extracted (TRIzol reagent; Invitrogen, Carlsbad, CA, USA) from the three groups of cells transfected for 48 hours (mock group, $50 \mathrm{nmol} / \mathrm{l} \mathrm{siCon}$, and $50 \mathrm{nmol} / \mathrm{l} \mathrm{siP} 53)$ and reverse transcribed using oligo(dT) primers and Moloney murine leukemia virus (M-MLV) reverse transcriptase (Promega, Madison, WI, USA). The resulting cDNA was amplified in a real-time PCR system (ABI Prism 7500; Applied Biosystems, CA, USA) using a commercial reagent (SYBR Premix Ex Taq $^{\text {TM }}$ Takara, Dalian, China). Values are expressed as fold difference compared with the mock group. Primer sequences for p53 and GADPH are shown in Table 1.

\section{Western blotting analysis}

Briefly, cells were harvested at 48 hours after dsRNA treatment as described above, washed, and lysed with lysis buffer. Protein concentration in the resulting lysate was determined using the bicinchoninic acid protein assay kit (Pierce Biotechnology Inc., Rockford, IL, USA). Appropriate amounts of protein $(30-50 \mu \mathrm{g})$ were resolved by electrophoresis in 8 to $12 \%$ Tris-glycine polyacrylamide gels and transferred to nitrocellulose membranes. Membranes were blocked and then incubated overnight with the appropriate primary antibody at dilutions specified by the manufacturer. They were next washed three times in $15 \mathrm{ml}$ Tris-buffered saline with Triton (TBS-T) and incubated with the corresponding horseradish peroxidase (HRP)-conjugated secondary antibody at 1:1000 dilution in TBS-T for 1 hour. The membranes were washed three times for 5 minutes each with $15 \mathrm{ml}$ TBS-T, then the bound secondary antibody was detected using an enhanced chemiluminescence (ECL) system (Pierce Biotechnology Inc.). 


\section{Cell growth/viability assay}

Proliferation of cells was determined by the (3-(4,5dimethylthiazol-2-yl)-2,5-diphenyltetrazolium bromide (MTT) assay. Approximately 3000 to 8000 (depending on how long they would be cultured) cells were plated in each well of a 96-well plate. After overnight incubation, the cells were treated with the appropriate dsRNA (mock, $50 \mathrm{nmol} / \mathrm{l} \mathrm{siCon}$, or $5-100 \mathrm{nmol} / \mathrm{l} \mathrm{siP53)}$ for 24 , 48 , or 72 hours, or with the dsRNA $(50 \mathrm{nmol} / \mathrm{l}$ siCon or siP53) for 24 hours, followed by incubation for 48 hours with or without $1 \mu \mathrm{g} / \mathrm{ml}$ cisplatin. At the various times after treatment, the medium was removed and MTT $(20 \mu \mathrm{l}$ of a $5 \mathrm{mg} / \mathrm{ml}$ solution) was added to each well, and plates were incubated at $37^{\circ} \mathrm{C}$ for 4 hours. After that, the plates were spun in a centrifuge, and the purple-colored formazan precipitate in each well was dissolved in $150 \mu \mathrm{l}$ of dimethyl sulfoxide. Absorbance was measured at $490 \mathrm{~nm}$ in an absorbance reader (MRX II ; DYNEX Technologies, Chantilly, VA, USA). The reduction in viability of each group was expressed as a percentage of the mock or siCon cells, which were considered to be $100 \%$ viable.

\section{Cell cycle analysis by flow cytometry}

Cell cycle analysis was performed using a commercial kit (Coulter DNA Prep ${ }^{\text {TM }}$ Reagents Kit; Beckman Coulter, Fullerton, CA, USA). Cells were plated in six-well plates and incubated overnight before treatment (mock, $50 \mathrm{nmol} / \mathrm{l}$ siCon and $50 \mathrm{nmol} / \mathrm{l}$ siP53 for 48 hours or $50 \mathrm{nmol} / \mathrm{l}$ siCon/siP53 for 24 hours with cisplatin or not for 48 hours-). Following treatment, cells were harvested, then washed twice with pre-chilled PBS and resuspended in 100 $\mu \mathrm{PBS}$ at a concentration of $1 \times 10^{6}$ cells $/ \mathrm{ml}$. Each cell sample was mixed with $100 \mu \mathrm{l}$ DNA Prep LPR (contained in Coulter DNA Prep ${ }^{\text {TM }}$ Reagents Kit), gently mixed by vortex and incubated in the dark at room temperature $\left(25^{\circ} \mathrm{C}\right)$ for 20 minutes. Then each was mixed with $1 \mathrm{ml}$ of stain (DNA Prep Stain; contained in Coulter DNA Prep ${ }^{\mathrm{TM}}$ Reagents Kit), gently mixed by vortex and again incubated in the dark at room temperature $\left(25^{\circ} \mathrm{C}\right)$ for 20 minutes. Finally, cell cycle analysis was performed within 1 hour using flow cytometry (Beckman Coulter FC500 Flow Cytometry System with CXP Software; Beckman Coulter, Fullerton, CA, USA), and the raw data was analyzed by Multicycle for Windows (Beckman Coulter).

\section{Detection of apoptotic cells by flow cytometry}

A quantitative assessment of apoptosis was made by determining the percentage of cells with highly condensed or fragmented nuclei. Cells were harvested at 48 hours after dsRNA treatment (mock, $50 \mathrm{nmol} / \mathrm{l}$ siCon, or 50 $\mathrm{nmol} / \mathrm{l}$ siP53) as described above, washed twice with pre-chilled PBS, and resuspended in $100 \mu \mathrm{l} 1 \times$ binding buffer at a concentration of $1 \times 10^{6}$ cells $/ \mathrm{ml}$. Double staining with fluorescein isothiscyanate (FITC)- conjugated annexin $\mathrm{V}$ and propidium iodide (PI) was performed (Annexin V-FITC Apoptosis Detection Kit; BD Biosciences, San Jose, CA, USA) in accordance with the manufacturer's protocol. Cell apoptosis analysis was performed within 1 hour by flow cytometry as described above.

\section{Statistical analysis}

All values are expressed as means \pm SD. Statistical significance was compared between treatment groups and controls using Student's $t$ test. $P<0.05$ was considered significant.

\section{Results}

\section{Silencing of p53 mutants in bladder cancer cells}

First, we checked the effects of the p53-targeting siRNA (siP53) on the expression of endogenous mutant p53 in 5637 and T24 human bladder cancer cell lines, which had been transfected with $50 \mathrm{nmol} / \mathrm{l}$ siP53 or a control dsRNA (siCon). At 48 hours after transfection, expression of p53 mRNA and protein was assessed by real-time quantitative PCR and western blotting respectively. Compared with the mock and siCon transfections, siP53 caused a reduction of more than $70 \%$ reduction in expression of the mutant p53 (Figure 1).

\section{Knockdown of mutant p53 inhibits the growth and viability of 5637 and T24 cells}

We next investigated the effects of knockdown of mutant p53 on bladder cancer cells. The two dsRNAs, siP53 and siCon, were respectively transfected into 5637 and T24 cells at a concentration of $50 \mathrm{nmol} / \mathrm{l}$. Phasecontrast images of cells from the same fields were taken 48 hours after transfection. Morphologically, the mock and siCon transfected cells maintained healthy growth, whereas the cells transfected with siP53 lost viability, and there was an evident decrease in cell number (Figure 2).

Following this, the effects of siP53 at varying concentrations and times ( 24 to 72 hours) on the proliferation and viability of 5637 and T24 cells were determined by the MTT assay. Inhibition of cell growth and viability by siP53 was dependent on dose and time (Figure 3). Reduction in 5637 cell viability with siP53 treatment at concentrations of 5 to $100 \mathrm{nmol} / \mathrm{l}$ after 72 hours ranged from $22.7 \%$ to $53.8 \%$, whereas reduction of cell viability in T24 cells ranged from $29.4 \%$ to $60.3 \%$ (Figure 3 ).

\section{Silencing of mutant p53 induces G2-phase cell cycle arrest in bladder cancer cells}

In addition to their ability to interfere with wild-type p53-mediated cell cycle arrest, many mutant p53 proteins can actively promote cell growth by affecting various proliferation-related genes [20,21]. Therefore, we 


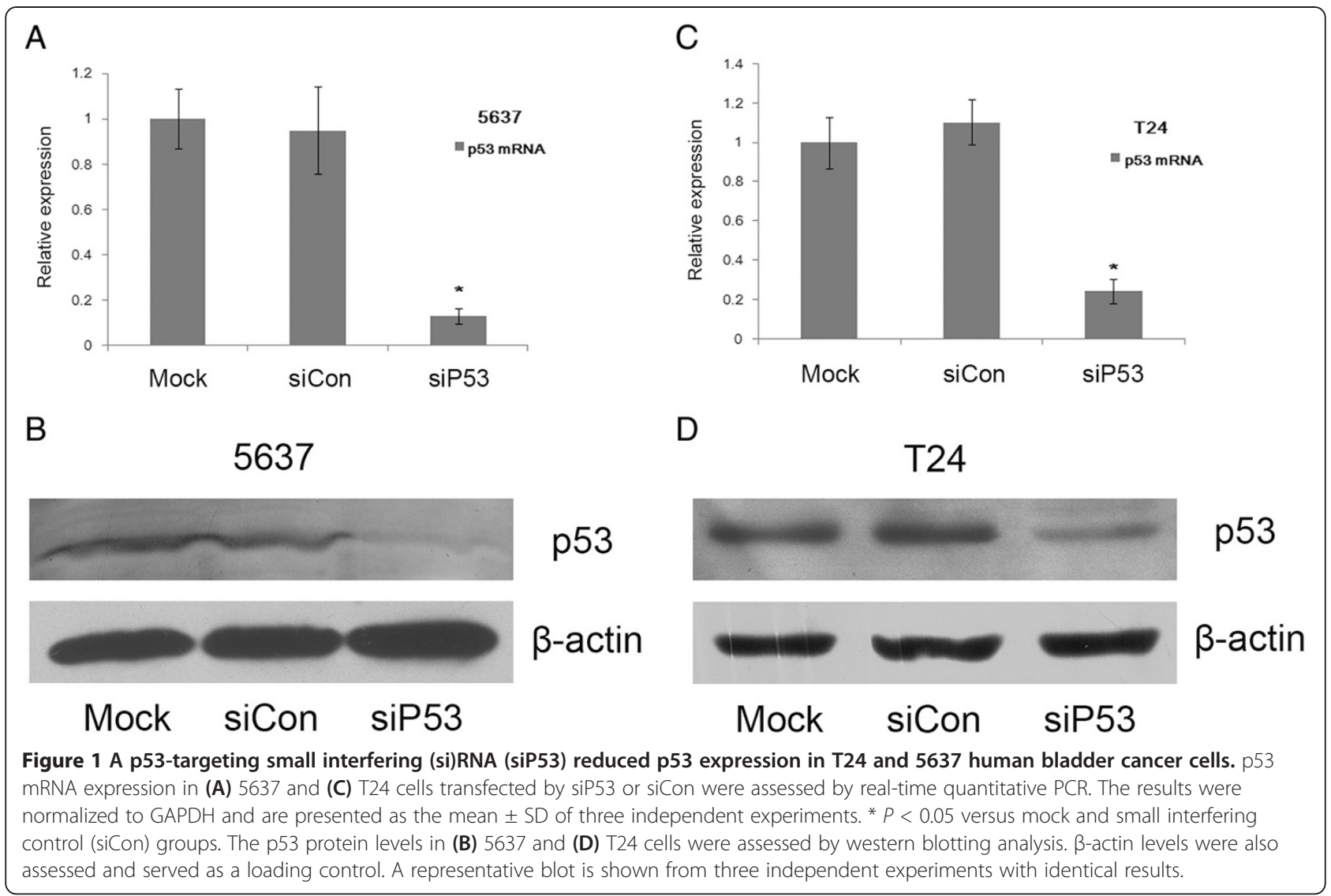

assessed whether siP53-induced inhibition of growth and viability is mediated via alterations in cell cycle regulation. The supernatant including suspended cells was removed and adherent live cells were harvested after 48 hours of treatment. G2 phase arrest was seen in cells treated with $50 \mathrm{nmol} / \mathrm{l}$ siP53 (Figure 4). The G2phase population of the siP53-treated 5637 cells was $32.39 \%$ at 48 hours after treatment, and increased by about $20 \%$ compared with controls, whereas the percentage of G2-phase T24 cells increased about 23\% after
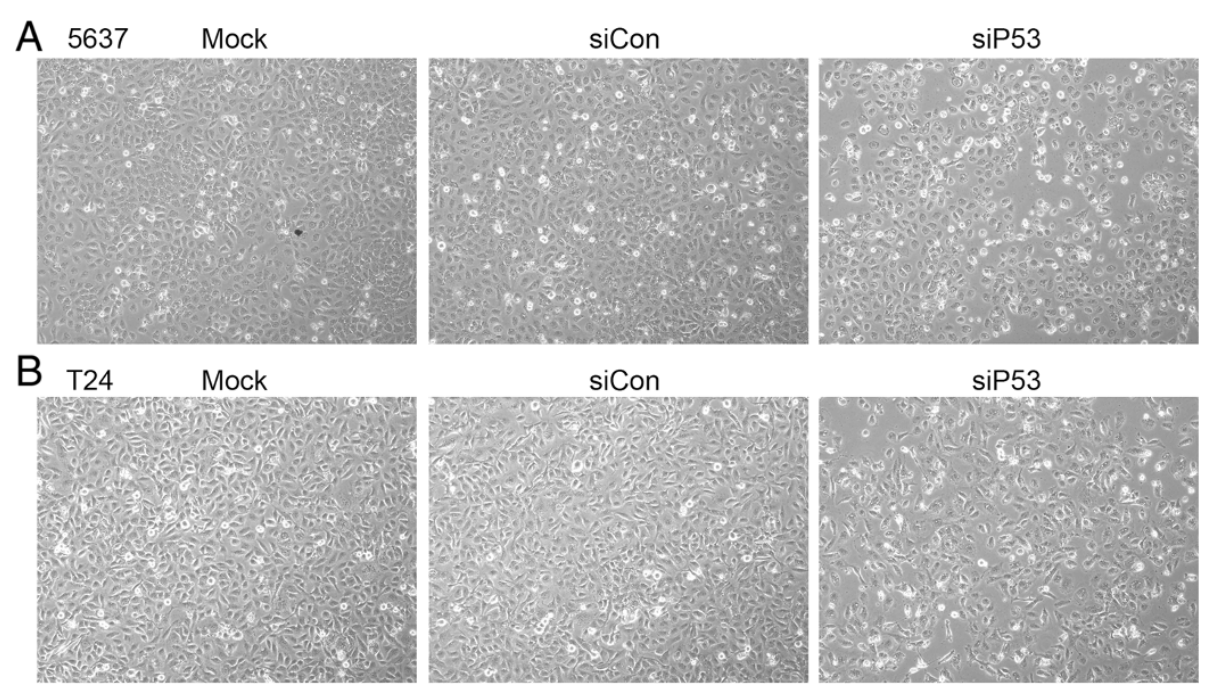

Figure 2 The p53-targeting small interfering (si)RNA (siP53) inhibited the growth of cells. (A) 5637 and (B) T24 cells were transfected with

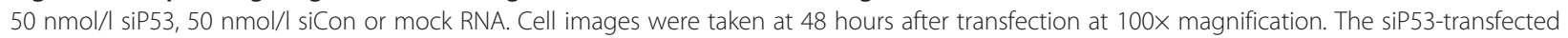
cells were less dense and had more dead cells in the culture than the cells in the siCon and mock groups. 


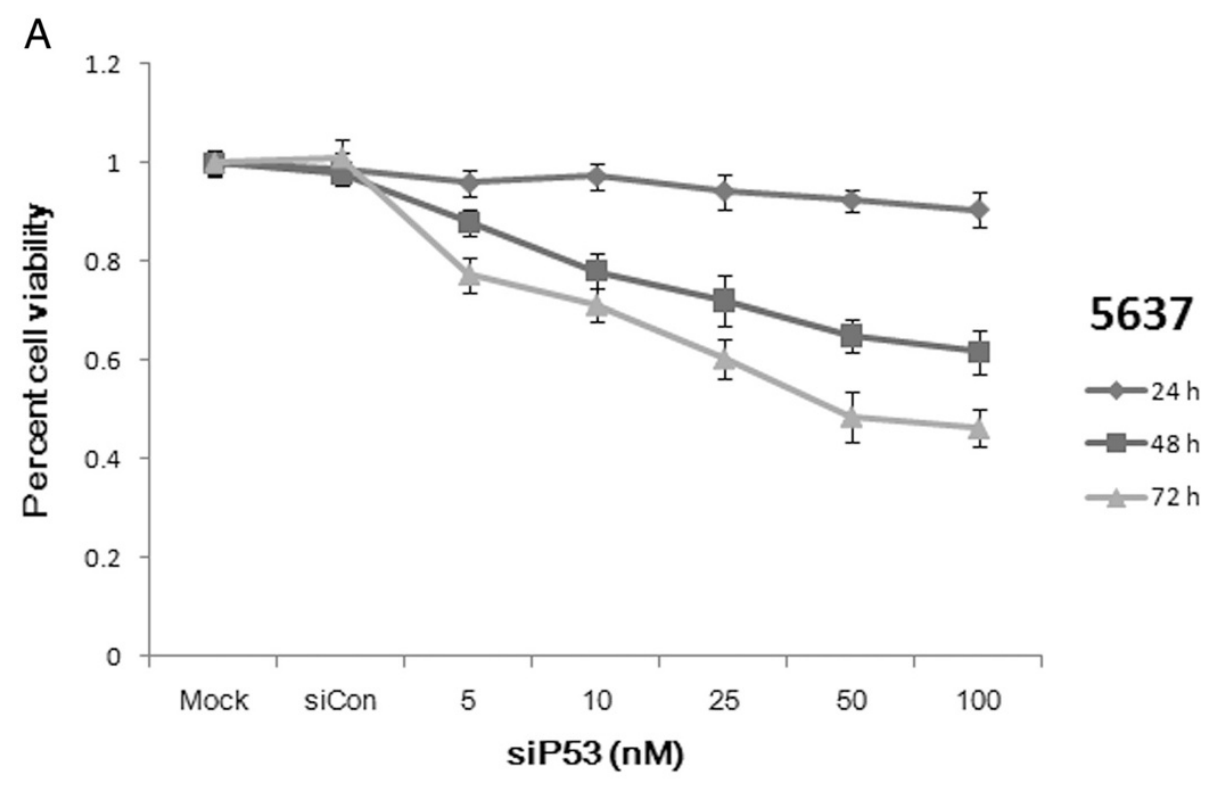

B

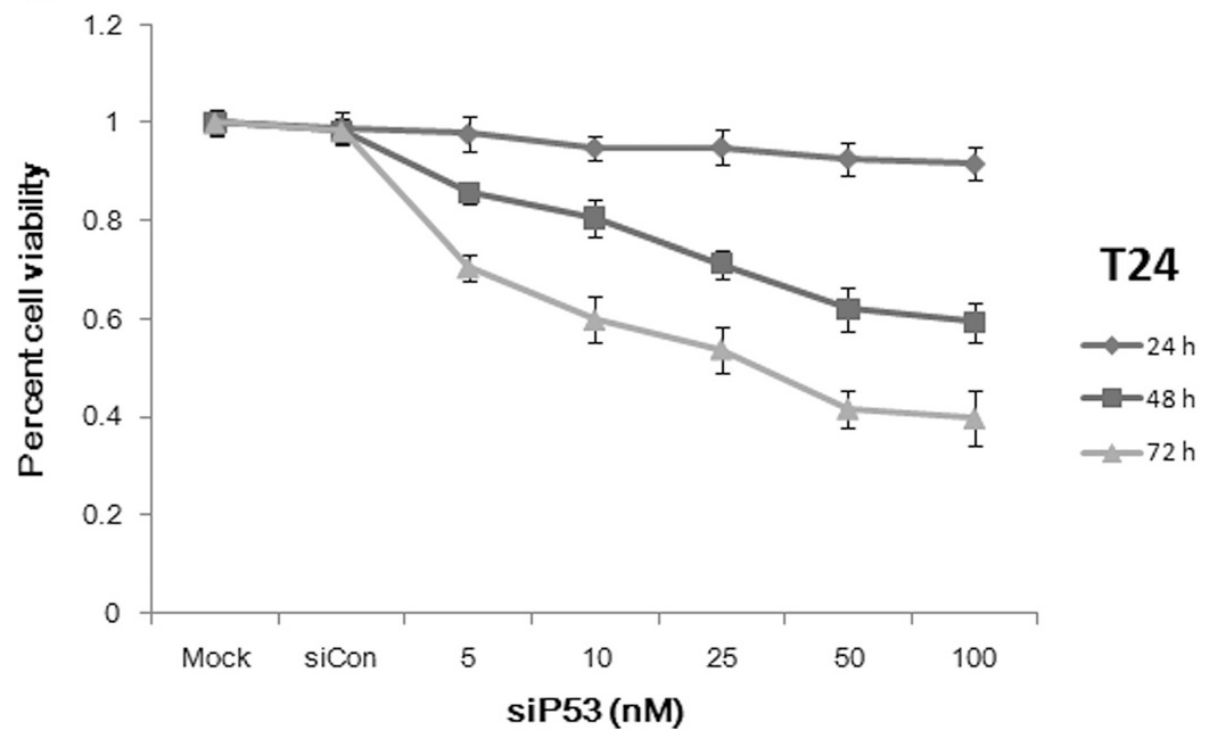

Figure 3 The small interfering (si)P53 inhibited the viability of cells in a dose-dependent and time-dependent manner, as assessed by the (3-(4,5-dimethylthiazol-2-yl)-2,5-diphenyltetrazolium bromide (MTT) assay. For both (A) 5637 and (B) T24 cells, reduced cell viability was seen after siP53 treatment ( 5 to $100 \mathrm{nmol} / \mathrm{l})$ at 24,48 , and 72 hours. Data are presented as means \pm SD $(n=8)$.

48 hours of treatment. The increase in cell population in the G2 phase was found to be associated with a concomitant significant decrease in the S-phase population.

Next, we examined the expression of several cell cycle-related proteins. Interference with the cell cycle in 5637 cells was associated with decreased expression of cyclin B1 and cyclin A, and reduced phosphorylation of CDK1, but no alteration in the expression of other cyclins and CDKs (Figure 5). The results of T24 cells are similar (data not sown).
Silencing of mutant p53 induces cell apoptosis in bladder cancer cells

We next investigated the relationship between siP53mediated loss of cell viability and apoptosis by flowcytometry analysis of 5637 cells labeled with PI and annexin V. We found that after 72 hours of treatment, siP53 caused evident apoptosis in 5637 cells. The number of early apoptotic cells (LR quadrant) increased to $6.2 \%$ in 5637 cells, and the number of late apoptotic cells (UR quadrant) increased to $17.9 \%$ (Figure 6A). These 


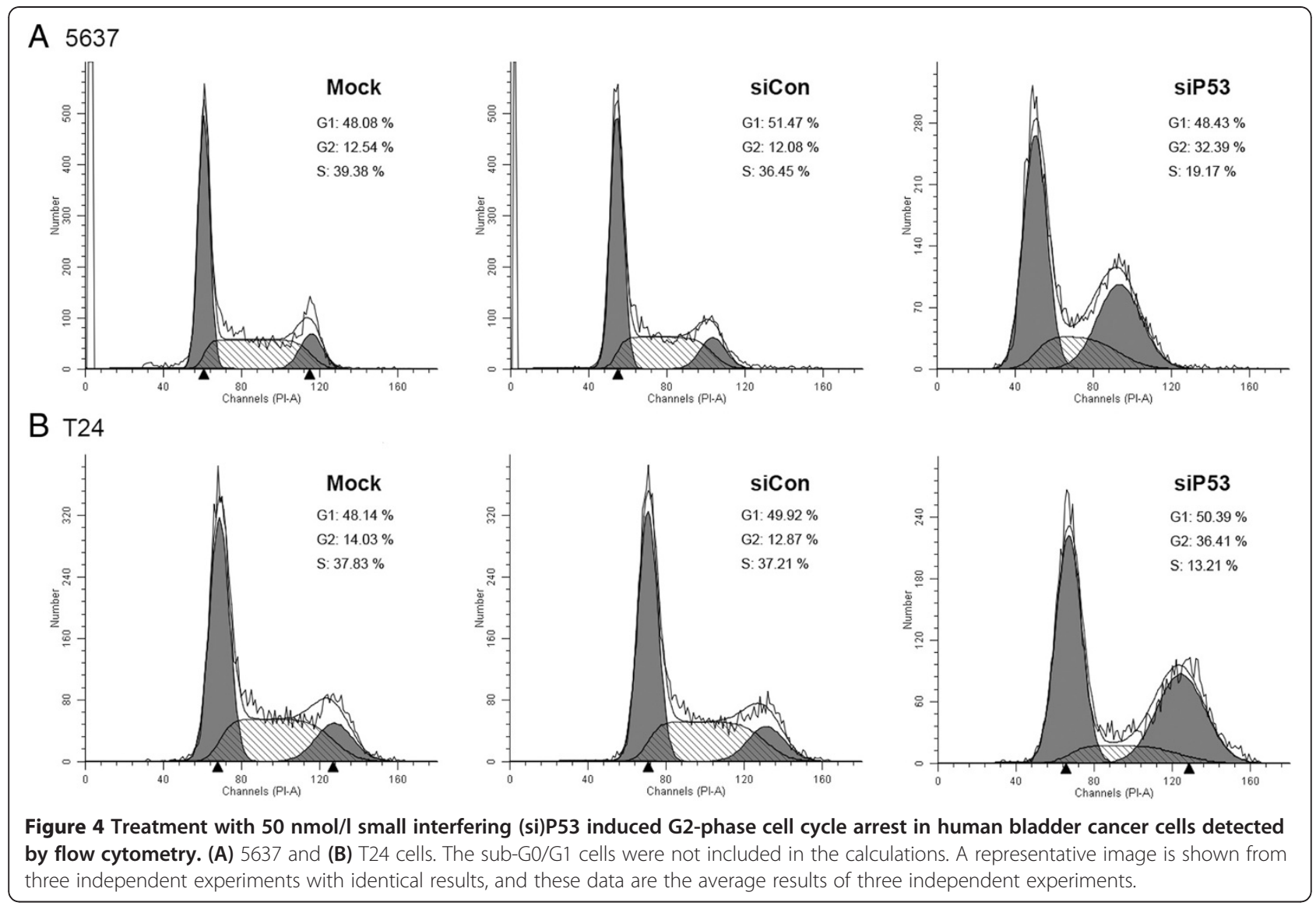

data also showed that siP53 treatment resulted in 6.3\% cell necrosis, which might be a secondary event in the apoptotic process. Similar results were also seen in T24 cells (data not shown).

Accordingly, activation of caspase 9 and caspase 3 and cleavage of PARP, which represent one of the final steps of the proteolytic caspase cascade and reliably indicate ongoing apoptosis, were present in siP53-treated 5637 cells (Figure 6B).

\section{Silencing of mutant p53 cooperates with cisplatin in producing inhibition of bladder cancer cells}

Cisplatin is the main chemotherapy drug for advanced bladder cancer. As explained in the Introduction, there have been conflicting findings as to whether p53 mutations confer increased responsiveness or increased resistance to cisplatin-based systemic chemotherapy in bladder cancer [17]. Thus, we used MTT assay to determine the combined effects of siP53 and cisplatin on 5637 bladder cancer cells.

After transfection with mock, siCon, or siP53 siRNAs for 24 hours, cells were sub-divided into two groups, and treated or not with $1 \mu \mathrm{g} / \mathrm{ml}$ cisplatin for another 48 hours. The average reduction in cell viability with siP53 + cispaltin treatment was $72.3 \%$ (Figure 7), which was much greater than the reduction obtained with the single treatment of siP53 (38.7\%) or cisplatin (44.9\%). Similar results were also seen in T24 cells (data not shown).

Both the live cells and the supernatant were then harvested to assess the effects of the treatment above by flow cytometry. Compared with the siCon-treated group, G2-phase arrest was seen in both the siP53-treated and cisplatin-treated groups (Figure 8). Moreover, there was a significant increase in the sub-G0/G1 population in these two groups ( $28.32 \%$ and $19.74 \%$, respectively), indicating apoptotic cells. When siP53-transfected cells were subsequently treated with cisplatin for 48 hours, the proportion of sub-G0/G1 cells increased to $51.51 \%$, suggesting that the p53-targeting siRNA can co-operate with cisplatin in the inhibition of bladder cancer cells.

\section{Discussion}

Mutations in the TP53 gene, encoding the p53 tumor suppressor, are arguably the most common type of genespecific alterations in human cancer. This emphasizes the pivotal role of p53 as a major mainstay of the body's built-in anticancer defense mechanisms. As the field of p53 research evolves, it is increasingly evident that many p53 mutants not only lose their own tumor-suppressive functions and acquire dominant-negative activities over 


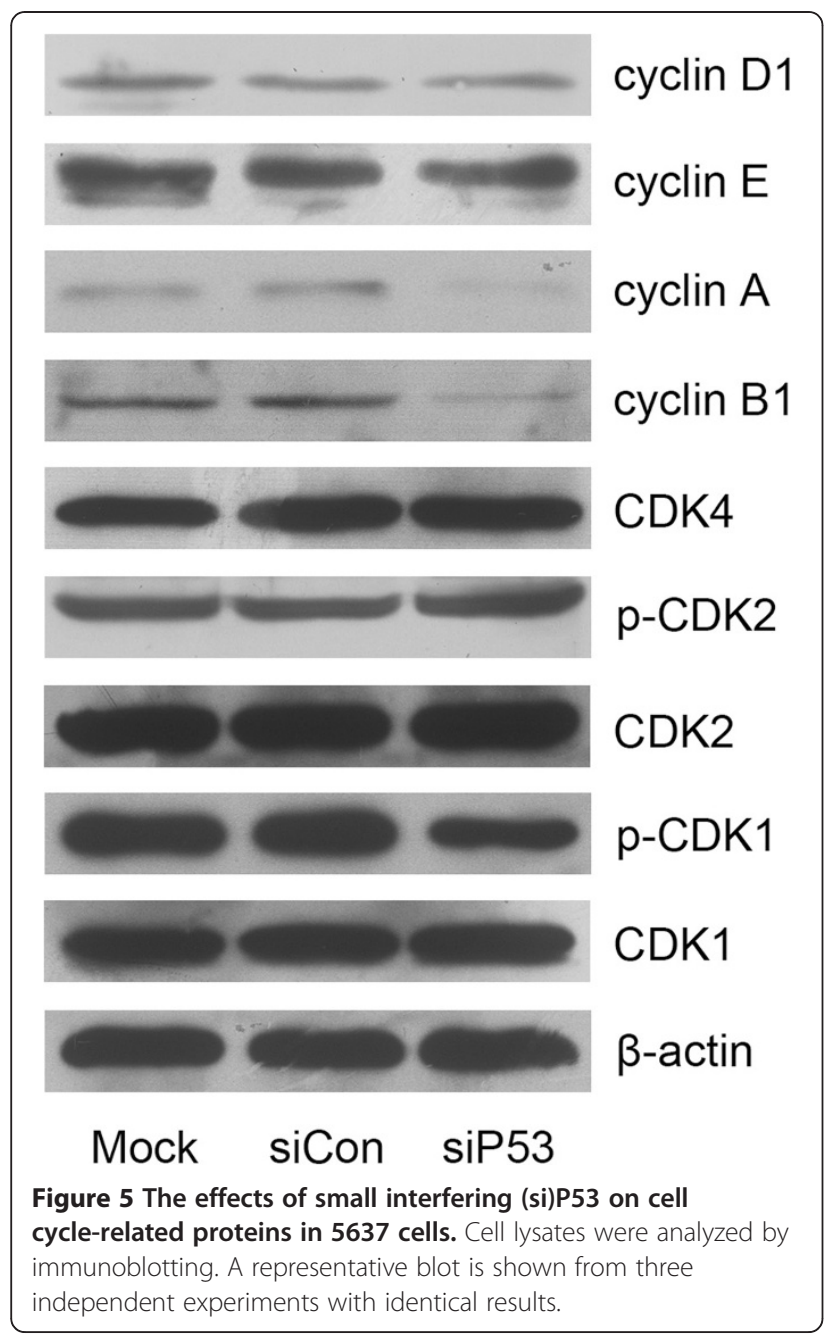

the remaining wild-type allele, but also gain new oncogenic properties that are not present in wild-type p53; this phenomenon is termed the 'gain-of-function hypothesis'. For instance, overexpression of p53 mutants in cultured cells was shown to interfere with apoptosis, enhance proliferation, and increase resistance of the cells to chemotherapy [22-24]. Moreover, transfection of mutant p53 into TP53-null cells was shown to enhance their ability to form tumors in mice [25]. Therefore, whereas wild-type p53 is a potent tumor suppressor, cancer-associated p53 mutants possess the attributes of oncogenes, suggesting that knockdown of mutant p53 may restrain or reverse the process of oncogenesis.

Recently, therapeutics based on RNA interference (RNAi) have become powerful and useful methods for the treatment of many diseases, including cancer, because of the high specificity, high efficacy and low toxicity of the RNAi trigger, small dsRNA [26,27]. Stable or conditional knockdown of endogenous mutant p53 by siRNAs in various human cancer cell lines, such as lung, breast, and colon cancer cells, has been reported to reduce their growth rate and chemoresistance in vitro, and their ability to form tumors in nude mice $[13,14,28]$. A recent study also obtained consistent results showing that siRNA targeting mutant p53 could induce cell cycle arrest and apoptosis in human prostate cancer cells [29]. In the current study, we used siRNAs that targeted p53 mutants to transfect human bladder cancer cell lines expressing only p53 mutants endogenously, and found that the transfection resulted in suppressed cell growth and viability via induction of cell cycle arrest and apoptotic cell death.

In numerous cancer types, mutations in TP53 are strongly associated with high expression levels of the proliferation-associated gene cluster, comprised mainly of the genes that participate in the core processes of the cell cycle [30]. Moreover, several p53 mutants were recently shown to repress wild-type p53 target genes, which encode pivotal cell cycle inhibitors (such as p21 and GADD45 $\alpha$ (growth arrest and DNA-damageinducible $45 \alpha)$ ), leading to alteration of cyclins/CDKs and an increased proliferation rate [31]. Whereas overcoming the G2/M checkpoint to initiate mitosis requires cyclin $\mathrm{B} / \mathrm{CDK} 1$ to be activated, cyclin A seems to be required for both S-phase and M-phase [32]. Cyclin A/ CDK2 drives G2-phase cells into mitosis, and is a ratelimiting component required for entry into mitosis [33]. Our analysis of cell cycle-related proteins showed that in the siP53-treated cells, there was significantly decreased expression of both cyclin B1 and cyclin A and reduced phosphorylation of CDK1, supporting the induction of G2 phase arrest detected by flow cytometry. Meanwhile, our study also showed activation of caspase- 9 and caspase- 3 and proteolytic cleavage of PARP in these cells, which play central roles during cell apoptosis [34,35].

Over the past two decades, cisplatin-based combination chemotherapy regimens, such as CMV (cisplatin, methotrexate, and vinblastin) or M-VAC (methotrexate, vinblastin, doxorubicin, and cisplatin) have been mainly used for patients with advanced bladder cancer [36-39]. However, because of their severe systemic toxicity and the poor overall prognosis of patients, novel therapeutic schemes containing different drug cocktails have been developed, with cisplatin occupying a central position in theseregimen (for example the GC (gemcitabine + cisplatin) regimen) [40]. It is generally accepted that DNA is the preferential and cytotoxic target for cisplatin [41-43]. Cisplatin-mediated damage of genomic DNA causes severe cell cycle perturbation and arrest at certain checkpoints, and in the absence of adequate repair, the affected cells undergo cell apoptosis. There has been controversy about the influence of mutant p53 on the responsiveness to the cisplatin-based systemic chemotherapy in bladder cancer [17]. Several studies have reported that patients with p53-altered bladder cancer benefited from adjuvant 

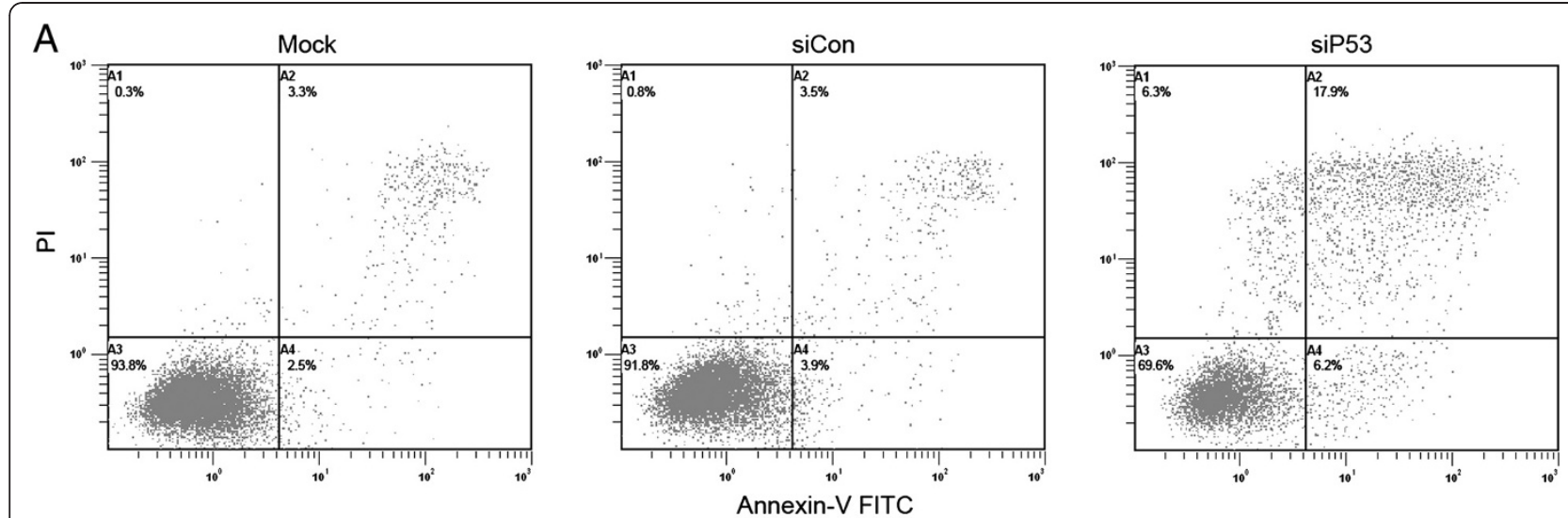

B

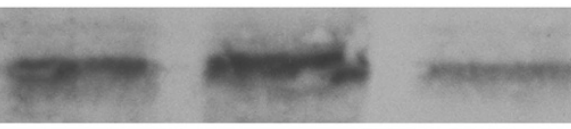

pro-caspase-9

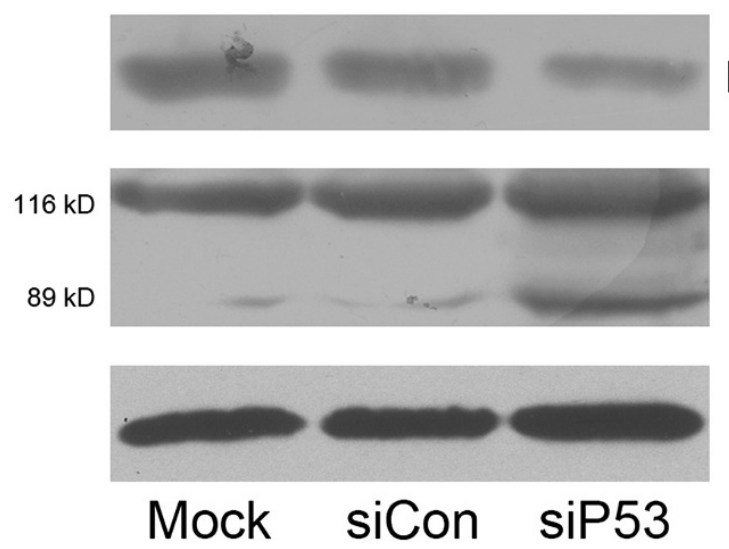

pro-caspase-3

\section{PARP}

\section{$\beta$-actin}

Figure 6 Small interfering (si)P53-induced apoptosis in 5637 human bladder cancer cells. (A) siP53 treatment resulted in apoptosis in 5637 cells detected by flow cytometry using a double-staining method with fluorescein thiocyanate-conjugated annexin $V$ and propidium iodide.

(B) siP53 treatment activated caspase-3, caspase-9, and poly(ADP-ribose) polymerase (PARP) in 5637 cells. Representative images and blots from three independent experiments with identical results are shown, and these data are the average results of three independent experiments.

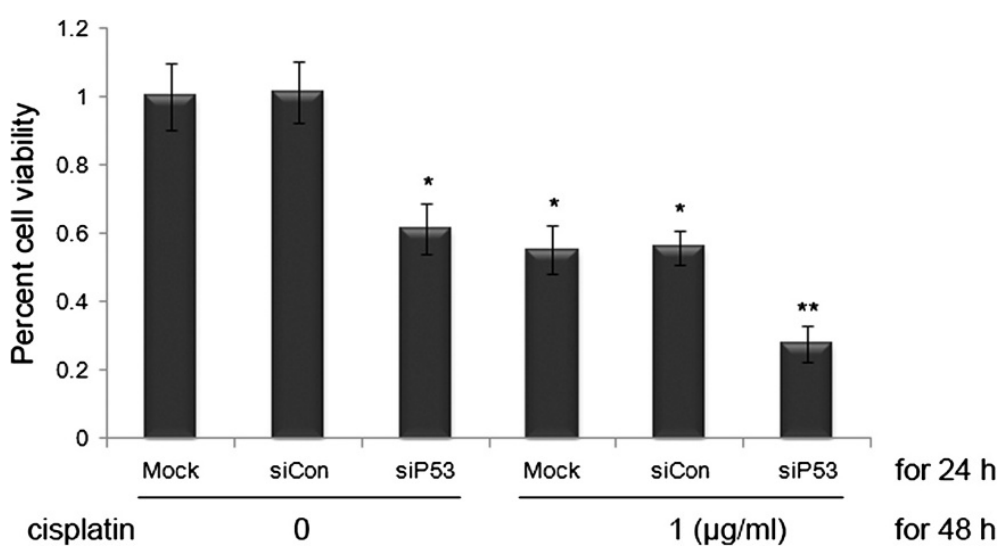

Figure 7 Silencing of mutant p53 cooperates with cisplatin in inhibiting the viability and growth of 5637 cells assessed by the (3-(4,5-dimethylthiazol-2-yl)-2,5-diphenyltetrazolium bromide (MTT) assay. These data are presented as means \pm SD $(n=8) .{ }^{*} P<0.05$ versus single treatment with the conrol (siCon) or mock DNA. ${ }^{* *} P<0.05$ versus single treatment with siP53 + cisplatin. 


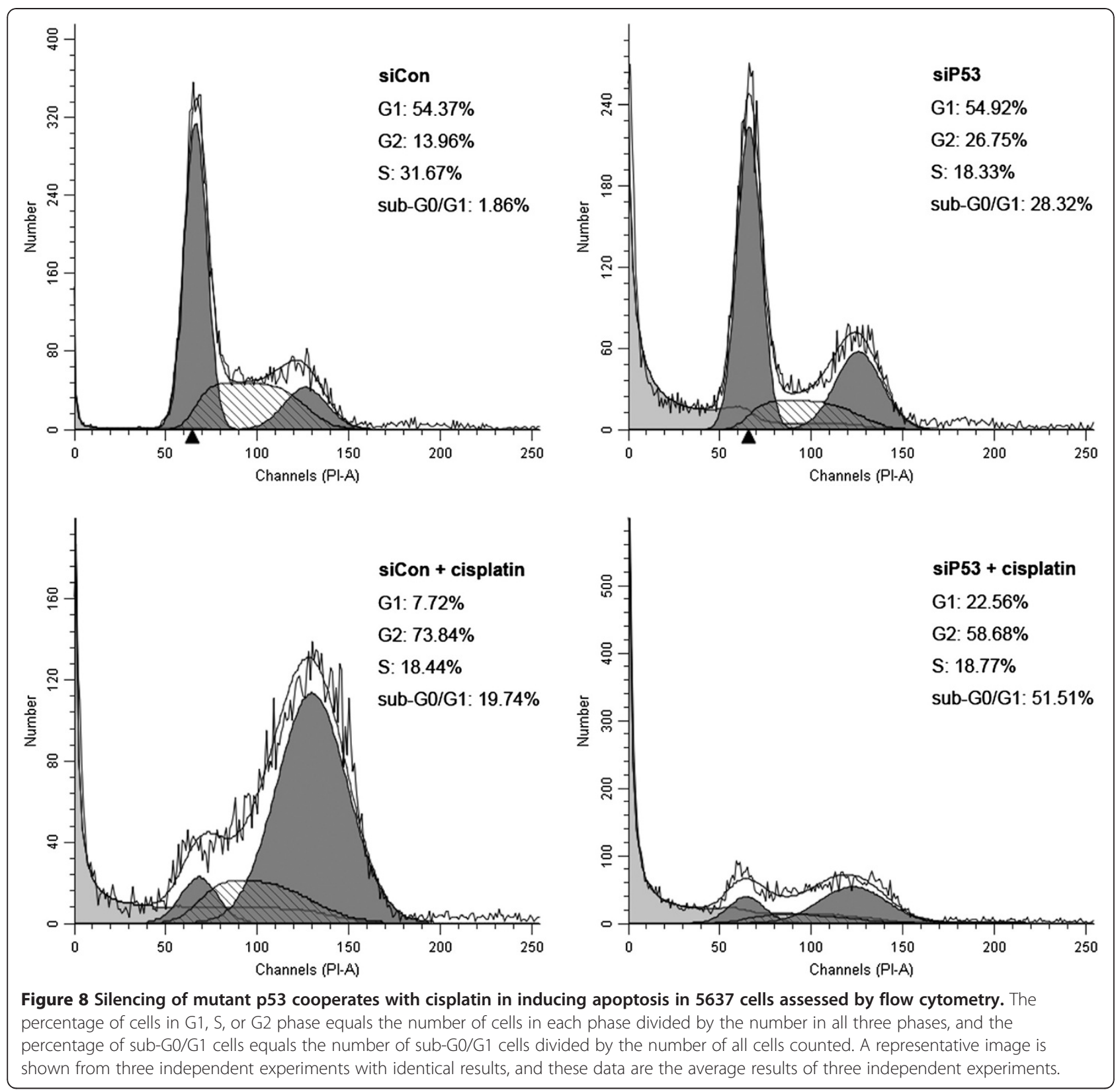

chemotherapy [44], whereas wild-type p53 was related to a poor response to systemic cisplatin-based chemotherapy [45], which might be related to the protection of cells from DNA damage by wild-type p53. However, other studies showed that mutations in TP53 were associated with drug resistance in several malignancies and cell lines [22,46], which might be partially attributable to transcriptional activation of the multi-drug resistance 1 (MDR1) gene $[47,48]$ and interference with apoptosis [23] by mutant p53. Therefore, targeting mutant p53 may sensitize the cancer cells to chemotherapy in at least some bladder cancers. In the current study, we found that knockdown of mutant p53 by siRNA in 5637 and T24 bladder cancer cells could co-operate with cisplatin and enhance its anticancer effects additively via increased cell apoptosis.

\section{Conclusions}

Our study indicated that knockdown of mutant p53 by siRNA was able to induce G2-phase cell cycle arrest and apoptosis in 5637 and T24 human bladder cancer cells. Moreover, this strategy cooperated with cisplatin in the inhibition of bladder cancer cells. Our results provide evidence that targeting mutant p53 by RNAi may serve as a promising therapeutic strategy for the treatment of partial advanced bladder cancer bearing p53 mutations. Despite the promise, the principal challenges that 
remain in achieving the broadest application of RNAi therapeutics are the hurdles of delivery and target validation in vivo. Further studies are needed to delineate the exact mechanism and verify in vivo effectiveness for clinical use in the future.

\section{Competing interests}

The authors declare that they have no competing interests.

\section{Authors' contributions}

$\mathrm{HBZ}, \mathrm{KY}$ and LPX conceived the study concept and participated in its design, data extraction, statistical analysis, manuscript drafting and editing. KY, YQX and YWL performed the experiment. QM participated in design and manuscript drafting. All authors read and approved the final manuscript.

\section{Acknowledgments}

This study was supported by grants from the National Natural Science Foundation of China (grant no. 81101718) and the National Key Clinical Specialty Construction Project of China.

\section{Author details}

'Department of Urology, The First Affiliated Hospital, School of Medicine, Zhejiang University, Qingchun Road 79, Hangzhou, Zhejiang Province 310003, China. ${ }^{2}$ Department of Gynecology, The First Affiliated Hospital, School of Medicine, Zhejiang University, Qingchun Road 79, Hangzhou, Zhejiang Province 310003, China.

Received: 7 July 2012 Accepted: 6 January 2013

Published: 28 January 2013

\section{References}

1. Siegel R, Naishadham D, Jemal A: Cancer statistics, 2012. CA Cancer J Clin 2012, 62:10-29.

2. Grossman HB, Natale RB, Tangen CM, Speights VO, Vogelzang NJ, Trump DL, deVere White RW, Sarosdy MF, Wood DP Jr, Raghavan D, Crawford ED: Neoadjuvant chemotherapy plus cystectomy compared with cystectomy alone for locally advanced bladder cancer. N Engl J Med 2003, 349:859-866.

3. Splinter TA, Scher HI, Denis L, Bukowski R, Simon S, Klimberg I, Soloway M, Vogelzang NJ, van Tinteren $\mathrm{H}$, Herr $\mathrm{H}$, European Organization for Research on Treatment of Cancer-Genitourinary Group: The prognostic value of the pathological response to combination chemotherapy before cystectomy in patients with invasive bladder cancer. J Urol 1992, 147:606-608.

4. Stenzl A, Cowan NC, De Santis M, Kuczyk MA, Merseburger AS, Ribal MJ, Sherif A, Witjes JA, European Association of Urology (EAU): Treatment of muscle-invasive and metastatic bladder cancer: update of the EAU guidelines. Eur Urol 2011, 59:1009-1018.

5. Green DR, Kroemer G: Cytoplasmic functions of the tumour suppressor p53. Nature 2009, 458:1127-1130

6. Vousden $\mathrm{KH}$, Prives C: Blinded by the light: the growing complexity of p53. Cell 2009, 137:413-431.

7. Hollstein M, Sidransky D, Vogelstein B, Harris CC: p53 mutations in human cancers. Science 1991, 253:49-53.

8. Vogelstein B, Lane D, Levine AJ: Surfing the p53 network. Nature 2000, 408:307-310.

9. Kato S, Han SY, Liu W, Otsuka K, Shibata H, Kanamaru R, Ishioka C Understanding the function-structure and function-mutation relationships of $\mathrm{p} 53$ tumor suppressor protein by high-resolution missense mutation analysis. Proc Natl Acad Sci USA 2003, 100:8424-8429.

10. Milner J, Medcalf EA, Cook AC: Tumor suppressor p53: analysis of wildtype and mutant p53 complexes. Mol Cell Biol 1991, 11:12-19.

11. Milner J, Medcalf EA: Cotranslation of activated mutant p53 with wild type drives the wild-type p53 protein into the mutant conformation. Cell 1991, 65:65-74.

12. Oren M, Rotter V: Mutant p53 gain-of-function in cancer. Cold Spring Harb Perspect Biol 2010, 2:a001107.

13. Bossi G, Lapi E, Strano S, Rinaldo C, Blandino G, Sacchi A: Mutant p53 gain of function: reduction of tumor malignancy of human cancer cell lines through abrogation of mutant p53 expression. Oncogene 2006, 25:304-309.
14. Bossi G, Marampon F, Maor-Aloni R, Zani B, Rotter V, Oren M, Strano S, Blandino G, Sacchi A: Conditional RNA interference in vivo to study mutant p53 oncogenic gain of function on tumor malignancy. Cell Cycle 2008, 7:1870-1879.

15. Mitra AP, Datar RH, Cote RJ: Molecular pathways in invasive bladder cancer: New insights into mechanisms, progression, and target identification. I Clin Oncol 2006, 24:5552-5564.

16. Bakkar AA, Wallerand H, Radvanyi F, Lahaye JB, Pissard S, Lecerf L, Kouyoumdjian JC, Abbou CC, Pairon JC, Jaurand MC, Thiery JP, Chopin DK, de Medina SG: FGFR3 and TP53 gene mutations define two distinct pathways in urothelial cell carcinoma of the bladder. Cancer Res 2003, 63:8108-8112.

17. Nishiyama H, Watanabe J, Ogawa O: $\mathbf{p} 53$ and chemosensitivity in bladder cancer. Int J Clin Oncol 2008, 13:282-286.

18. Cooper MJ, Haluschak JJ, Johnson D, Schwartz S, Morrison LJ, Lippa M, Hatzivassiliou G, Tan J: p53 mutations in bladder carcinoma cell lines. Oncol Res 1994, 6:569-579.

19. Riegerl KM, Little AF, Swart JM, Kastrinakis WW, Fitzgerald JM, Hess DT, Libertino JA, Summerhayes IC: Human bladder carcinoma cell lines as indicators of oncogenic change relevant to urothelial neoplastic progression. Br J Cancer 1995, 72:683-690.

20. Weisz L, Oren M, Rotter V: Transcription regulation by mutant $\mathrm{p} 53$. Oncogene 2007, 26:2202-2211.

21. Donzelli S, Biagioni F, Fausti F, Strano S, Fontemaggi G, Blandino G: Oncogenomic approaches in exploring gain of function of mutant p53. Curr Genomics 2008, 9:200-207.

22. Blandino G, Levine AJ, Oren M: Mutant p53 gain of function: differential effects of different p53 mutants on resistance of cultured cells to chemotherapy. Oncogene 1999, 18:477-485.

23. Li R, Sutphin PD, Schwartz D, Matas D, Almog N, Wolkowicz R, Goldfinger N, Pei H, Prokocimer M, Rotter V: Mutant p53 protein expression interferes with p53-independent apoptotic pathways. Oncogene 1998, 16:3269-3277.

24. Bergamaschi D, Gasco M, Hiller L, Sullivan A, Syed N, Trigiante G, Yulug I, Merlano M, Numico G, Comino A, Attard M, Reelfs O, Gusterson B, Bell AK Heath V, Tavassoli M, Farrell PJ, Smith P, Lu X, Crook T: p53 polymorphism influences response in cancer chemotherapy via modulation of p73-dependent apoptosis. Cancer Cell 2003, 3:387-402.

25. Wolf $\mathrm{D}$, Harris $\mathrm{N}$, Rotter $\mathrm{V}$ : Reconstitution of $\mathrm{p} 53$ expression in a nonproducer Ab-MuLV-transformed cell line by transfection of a functional p53 gene. Cell 1984, 38:119-126.

26. Bumcrot D, Manoharan M, Koteliansky V, Sah DW: RNAi therapeutics: a potential new class of pharmaceutical drugs. Nat Chem Biol 2006, 2:711-719.

27. Castanotto D, Rossi Jj: The promises and pitfalls of RNA-interferencebased therapeutics. Nature 2009, 457:426-433.

28. Ma LL, Sun WJ, Wang Z, Zh GY, Li P, Fu SB: Effects of silencing of mutant p53 gene in human lung adenocarcinoma cell line Anip973. J Exp Clin Cancer Res 2006, 25:585-592.

29. Zhu H, Mao Q, Lin Y, Yang K, Xie L: RNA interference targeting mutant p53 inhibits growth and induces apoptosis in DU145 human prostate cancer cells. Med Oncol 2011, 28(Suppl 1):S381-S387.

30. Whitfield ML, George LK, Grant GD, Perou CM: Common markers of proliferation. Nature Rev Cancer 2006, 6:99-106.

31. Vikhanskaya F, Lee MK, Mazzoletti M, Broggini M, Sabapathy K: Cancer-derived p53 mutants suppress p53-target gene expression-potential mechanism for gain of function of mutant p53. Nucleic Acids Res 2007, 35:2093-2104.

32. Pagano M, Pepperkok R, Verde F, Ansorge W, Draetta G: Cyclin A is required at two points in the human cell cycle. EMBO J 1992, 11:961-971.

33. Furuno $\mathrm{N}$, den Elzen $\mathrm{N}$, Pines J: Human cyclin $\mathrm{A}$ is required for mitosis until mid prophase. J Cell Biol 1999, 147:295-306.

34. Salvesen GS, Dixit VM: Caspase activation: the induced proximity model. Proc Natl Acad Sci USA 1999, 96:10964-10967.

35. Germain M, Affar EB, D'Amours D, Dixit VM, Salvesen GS, Poirier GG: Cleavage of automodified poly (ADP-ribose) polymerase during apoptosis: evidence for involvement of caspase-7. J Biol Chem 1999, 274:28379-28384.

36. Lehmann J, Retz M, Stockle M: Chemotherapy in the post-MVAC era: the case for adjuvant chemotherapy. World J Urol 2002, 20:144-150.

37. Ardavanis A, Tryfonopoulos D, Alexopoulos A, Kandylis C, Lainakis G, Rigatos $\mathrm{G}:$ Gemcitabine and docetaxel as first-line treatment for advanced urothelial carcinoma: a phase II study. Br J Cancer 2005, 92:645-650. 
38. Rosenberg JE, Carroll PR, Small EJ: Update on chemotherapy for advanced bladder cancer. J Urology 2005, 174:14-20.

39. Theodore C, Geoffrois L, Vermorken JB, Caponigro F, Fiedler W, Chollet P, Ravaud A, Peters GJ, de Balincourt C, Lacombe D, Fumoleau P: Multicentre EORTC study 16997: feasibility and phase II trial of farnesyl transferase inhibitor \& gemcitabine combination in salvage treatment of advanced urothelial tract cancers. Eur J Cancer 2005, 41:1150-1157.

40. Perabo FG, Muller SC: New agents for treatment of advanced transitional cell carcinoma. Ann Oncol 2007, 18:835-843.

41. Rabik CA, Dolan ME: Molecular mechanisms of resistance and toxicity associated with platinating agents. Cancer Treat Rev 2007, 33:9-23.

42. Kelland $\mathrm{L}$ : The resurgence of platinum-based cancer chemotherapy. Nat Rev Cancer 2007, 7:573-584.

43. Ho YP, Au-Yeung SC, To KK: Platinum-based anticancer agents: innovative design strategies and biological perspectives. Med Res Rev 2003, 23:633-655

44. Cote RJ, Esrig D, Groshen S, Jones PA, Skinner DG: P53 and treatment of bladder cancer. Nature 1997, 385:123-124.

45. Watanabe J, Nishiyama H, Okubo K, Takahashi T, Toda Y, Habuchi T, Kakehi Y, Tada M, Ogawa O: Clinical evaluation of p53 mutations in urothelial carcinoma by IHC and FASAY. Urology 2004, 63:989-993.

46. Lu C, El-Deiry WS: Targeting p53 for enhanced radio- and chemosensitivity. Apoptosis 2009, 14:597-606.

47. Chin KV, Ueda K, Pastan I, Gottesman MM: Modulation of activity of the promoter of the human MDR1 gene by Ras and p53. Science 1992, 255:459-462.

48. Bush JA, Li G: Cancer chemoresistance: the relationship between p53 and multidrug transporters. Int J Cancer 2002, 98:323-330.

doi:10.1186/1477-7819-11-22

Cite this article as: Zhu et al:: Silencing of mutant p53 by siRNA induces cell cycle arrest and apoptosis in human bladder cancer cells. World Journal of Surgical Oncology 2013 11:22.

\section{Submit your next manuscript to BioMed Central and take full advantage of:}

- Convenient online submission

- Thorough peer review

- No space constraints or color figure charges

- Immediate publication on acceptance

- Inclusion in PubMed, CAS, Scopus and Google Scholar

- Research which is freely available for redistribution 